\title{
CORRESPONDENCE
}

The Editor,

Journal of Glaciology

SIR,

\section{Early descriptions of pro-talus ramparts}

I refer to the correspondence in Journal of Glaciology, Vol. 33, No. 114, involving Butler, Porter, and Ballantyne, concerning the scientific primacy of the recognition of the pro-talus rampart as a (moderately) distinct land form. Like Porter, I think that the description by Drew (1873) of forms in the upper Indus, which was taken up by Ward (1873) to explain fossil features in the English Lake District, should be accorded primacy.

These descriptions are both part of much more general regional accounts, so it would be a pity to let this correspondence close without drawing attention to a little known paper by Kendall (1893) which is entirely devoted to a detailed description of such a form. Both the title of the work, "On a moraine-like mound near Snowdon", and the following quotation:

"at the close of the Glacial Epoch, when the Welsh glaciers had entirely passed away, there would be perennial snow banks in a thousand such sheltered corners. The nearer to the time of the great severity the more considerable would the snow banks be. Suppose now, we imagine a huge snow wreath banked up against the cliffs of $\mathrm{Cwm} \mathrm{Du}$. The weather would attack the lofty scarps, water would percolate between the columns of lava, and, freezing, force them upward, so that the stone showers so familiar to Alpine travellers would be produced here under conditions highly favourable to their development; but when the stones come down they would find the base of the cliffs pre-occupied by a talus of snow, therefore they would roll further out from the base and form a fringe of rock debris"

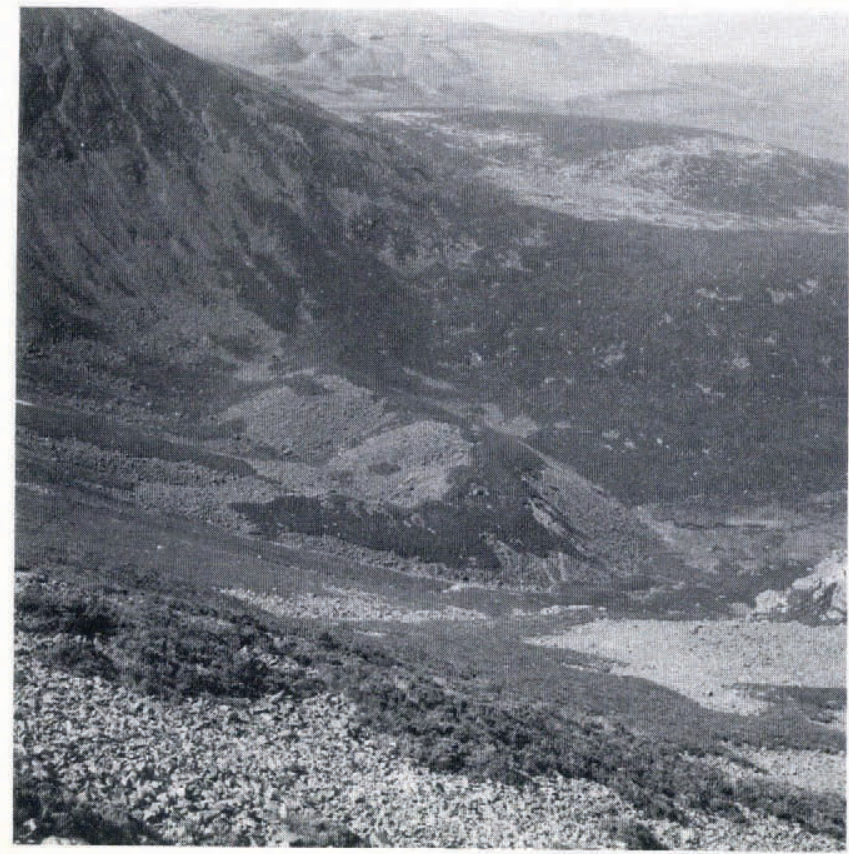

Fig. 1. The pro-talus rampart in Cwm Du, Snowdonia, North Wales. gives little doubt what Kendall had in mind.

The photograph (Fig. 1), taken in the mid 1960s, shows the feature which is at grid reference (OS) SH 536553. Since Kendall's visit, the site has been mapped by myself (Unwin, 1975, fig. 2) and more recently still by Gray (1982) who puts it into its regional and chronological context.

Department of Geography,

University of Leicester.

DAvid J. UnWIN

Leicester $L E I 7 R H$,

England

16 September 1987

\section{REFERENCES}

Drew, F. 1873. Alluvial and lacustrine deposits and glacial records of the Upper-Indus basin. Quarterly Journal of the Geological Society of London, 29, 441-71.

Gray, J.M. 1982. The last glaciers (Loch Lomond readvance) in Snowdonia, N. Wales. Geological Journal, 17, 111-33.

Kendall, P.F. 1893. On a moraine-like mound near Snowdon. Glacialist Magazine, 1, 68-70.

Unwin, D.J. 1975. The nature and origin of the corrie moraines of Snowdonia. Cambria, 2(1), 20-33.

Ward, C. 1873. The glaciation of the northern part of the Lake District. Quarterly Journal of the Geological Society of London, 29, 422-41.

SIR,

\section{Early descriptions of pro-talus ramparts}

Recent correspondence in the Journal of Glaciology concerning early descriptions of pro-talus ramparts (Butler, 1986, 1987; Ballantyne, 1987; Porter, 1987) has failed to include mention of an interesting account of these features, and their mode of formation, from Ireland (Kinahan, 1894). There are few detailed descriptions of pro-talus ramparts in Ireland and consequently Kinahan's paper, while being known to Irish glacial and periglacial geomorphologists as an early and important contribution to the subject (Warren, 1979; Lewis, 1985), is probably unknown beyond these shores.

Although Kinahan's report was published 21 years after those by Drew (1873) and Ward (1873), he had identified

"some forty years ago ... peculiar accumulations evidently in some way due to ice or its adjuncts".

He originally attributed these features to

"the Glacial period; while knowledge since gained would seem to prove that these terminal moraines may possibly be accumulating at the present day".

Despite naming such features "terminal moraines", Kinahan's account of their formation clearly indicates that the debris travelled across the surface of an inclined snow bed

"In the cooms and under the high cliffs great snow drifts accumulated .... . As is always the case after a severe frost, blocks and other detritus are displaced by falls when the thaw comes on; and if the fall is from a cliff over one of these drifts, the blocks and other stuff slide over it and form round its edge a terminal moraine". 